\title{
“MENGGIRING" ECONOMIC VALUE OF TIME MENJADI TIME VALUE OF MONEY (TELAAH KRITIS PENGGUNAAN ANUITAS)
}

\author{
Vaisal Amir \\ Universitas Brawijaya, Jl. MT. Haryono 165, Malang \\ Surel: vaisal_amir@yahoo.com
}

\begin{abstract}
Abstrak. "Menggiring" Economic Value of Time menjadi Time Value of Money (Telaah Kritis Penggunaan Anuitas). Tujuan penelitian ini adalah untuk mengetahui dan menjelaskan lebih jauh mengenai konsep economic value of time apakah sudah sesuai dengan semangat ekonomi Islam jika dibandingkan dengan legalisasi penggunaan rumus matematika teori ekonomi konvensional. Penelitian ini termasuk dalam kategori kajian literatur kritis dimana nilai-nilai Islam menjadi landasan filosofisnya. Temuan penelitian ini menunjukkan bahwa penggunaan anuitas (sebagai representasi penggunaan perhitungan matematis dalam ekonomi Islam) pada hakikatnya masih mengandung unsur semangat kapitalisme dan ketidakadilan yang notabene sudah keluar dari aturan syariah. Di dalam anuitas juga masih melekat semangat pelanggengan riba', dimana anuitas masih menggunakan nilai waktu dari uang (time value of money).
\end{abstract}

Abstract. "Directing" Economic Value of Time Become Time Value of Money (Critical Study the Use of Annuity). The purpose of this study is to know and more explain about the concept of economic value of time that already in line with the spirit of Islamic economics if compared by the use of legalization mathematical formulas of conventional economic theory. This study include to the category of critical literature review which Islamic values become a philosophical foundation. The findings of this study indicate that the use of annuity (as a representation the use of mathematical calculation in Islamic economy) is essentially still contains elements of capitalism spirit and injustice which in fact is already out of the syariah rules. Annuity still included with the spirit of riba' perpetuation, which still used time value of money.

Kata kunci: Economic Value of Time, Time Value of Money, Anuitas

Dalam menjalani sebuah kehidupan setiap manusia tentunya memerlukan suatu kegiatan ekonomi. Sejak jaman pra sejarah sampai dengan saat ini manusia melakukan transaksi ekonomi untuk memenuhi kebutuhan hidup mereka. Sebagaimana penjelasan Deliarnov (2003) yang dikutip oleh Byarwati dan Sawarjuwono (2013) yang menyatakan bahwa istilah ekonomi telah digunakan selama berabad-abad, dan telah menjadi bagian yang menyertai perjalanan kehidupan manusia. Kata "ekonomi" berasal dari penggabungan dua suku kata Yunani: oikos (oikos) yang berarti "keluarga, rumah tangga" dan vó $\mu$ os (nomos), yang berarti "peraturan, aturan, hukum," dan secara garis besar diartikan sebagai "aturan keluarga (rumah tangga)" atau "manajemen keluarga (rumah tangga)". Lebih lanjut dijelaskan bahwa ekonomi adalah aturan-aturan untuk menyelenggarakan kebutuhan hidup manusia di dalam rumah tangga, baik dalam rumah tangga individu maupun dalam rumah tangga yang bersifat kolektif dalam suatu negara, atau secara populer, ekonomi didefinisikan sebagai pengetahuan tentang peristiwa dan persoalan yang berkaitan dengan upaya manusia secara

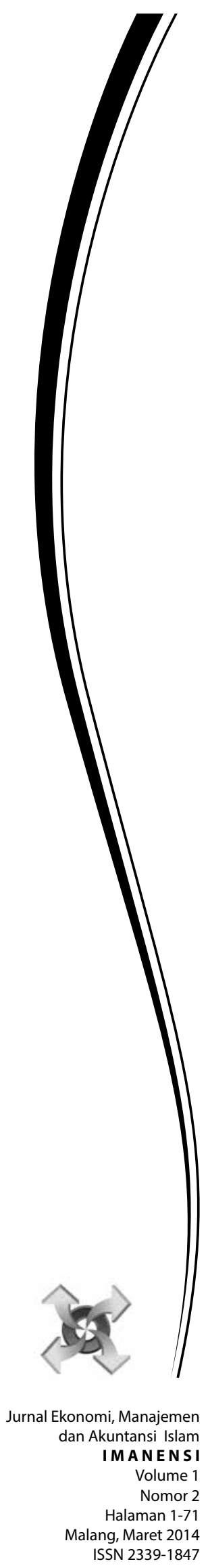


perseorangan (pribadi), kelompok (keluarga, suku bangsa, organisasi) dalam memenuhi kebutuhan yang tidak terbatas dan dihadapkan pada sumber yang terbatas.

Pengertian umum mengenai ekonomi tentunya tidaklah sama, setiap mahzab ekonomi memiliki suatu pengertian kontekstual ekonomi yang berbeda terutama mahzab ekonomi konvensional dan ekonomi Islam. Ash Shadr (2008:79-80) menjelaskan perbedaan pemaknaan ekonomi ke dalam dua bentuk, yaitu ekonomi sebagai ilmu dan ekonomi sebagai doktrin. Ekonomi sebagai doktrin menunjukkan cara atau metode yang dipilih dan diikuti suatu kelompok masyarakat dalam kehidupan eknominya serta dalam memecahkan setiap masalah praktis yang dihadapinya. Sedangkan ekonomi sebagai ilmu merupakan sebuah ilmu yang berhubungan dengan penjelasan terperinci mengenai kehidupan ekonomi, peristiwaperistiwanya, gejala-gejala lahiriahnya, serta hubungan antara peristiwa-peristiwa dan fenomena-fenomena tersebut dengan sebabsebab dan faktor-faktor umum yang mempengaruhinya. Lebih jauh lagi Ash Shadr (2008:80) menjelaskan bahwa ekonomi Islam merupakan sebuah doktrin bukan sebuah ilmu, karena ekonomi Islam merupakan cara yang direkomendasikan Islam dalam mengejar kehidupan ekonomi.

Berdasarkan penjelasan di atas, kita dapat menyimpulkan bahwa perbedaan utama antara mahzab ekonomi konvensional dan Islam terletak pada "pegangan" atau landasan filosofis serta tujuan melakukan kegiatan ekonomi. Ekonomi konvensional lebih menyandarkan pada aspek-aspek materiil kemanusiawian, sedangkan ekonomi Islam lebih seimbang, di mana dalam meraih kesenangan duniawi di dasarkan kepada aturan-aturan Tuhan yang lebih bersifat spiritual-religius. Hal tersebut diperkuat oleh pernyataan Mannan (1992:29) yang menerangkan bahwa hukum ekonomi Islam terdiri atas Al-Qur'an, Hadist, Ijma', Qiyas, dan Ijtihad. Sehingga tidak mengherankan jika argumen-argumen yang mendasari prinsip-prinsip ekonomi konvensional lebih menitik beratkan kepada kuantitas, sedangkan ekonomi Islam lebih kepada kualitas, terutama kualitas umat yang menjalankan prinsip-prinsip tersebut. Hal tersebut tercermin dalam konsep mengenai uang, di mana ekonomi konvensional mengakui time value of money (nilai waktu atas uang) yang menganggap uang sebagai komoditas, sedan- gkan Islam lebih mengakui economic value of time (nilai ekonomis atas waktu) yang menganggap nilai ekonomis waktu tergantung pertambahan pendapatan atas operasional yang dilakukannya. Pengakuan atas praktik time value of money dalam ekonomi konvensional pada akhirnya menimbulkan konsekuensi bahwa praktik ekonomi konvensional lebih dekat dengan praktik riba' yang diharamkan di dalam agama Islam dan pada akhirnya praktik ekonomi Islam yang mengakui economic value of time-lah yang dirasa adil dan sesuai dengan kegiatan ekonomi syariah yang ada saat ini.

Namun, pada kenyatannya terkadang masyarakat dibingungkan dengan konsep economic value of time yang ada dalam tataran praktis saat ini. Kebingunan masyarakat lebih dikarenakan cara perhitungan dan penentuan prosentase maupun perhitungan lainnya yang menyangkut pembiayaan syariah lebih mirip dengan cara perhitungan dan penentuan prosentase marjin keuntungan maupun bagi hasil dalam konsep ekonomi konvensional. Karim (2011:503) berpendapat bahwa walaupun konsep time value of money terbantahkan, bukan berarti perangkat matematis yang digunakan oleh konsep tersebut tidak dapat dipakai lagi. Rumus matematika yang digunakan dalam teori keuangan konvensional pada dasarnya dapat juga digunakan dalam keuangan syariah, misalnya untuk menentukan tingkat keuntungan yang diminta oleh bank syariah. Yang menjadi pertanyaan atas pernyataan Karim (2011) tersebut adalah apakah penggunaan rumus matematika dalam teori keuangan konvensional yang mengakui time value of money dalam penentuan marjin keuntungan perbankan syariah membawa konsekuensi mengakui time value of money juga?

Berdasarkan permasalahan yang ada, maka tujuan penelitian ini adalah untuk mengetahui dan menjelaskan lebih jauh mengenai konsep economic value of time yang ada sudah sesuai dengan semangat ekonomi Islam jika dibandingkan dengan legalisasi penggunaan rumus matematika teori ekonomi konvensional. Hasil dari kajian literatur ini diharapkan dapat memberikan informasi dan pengetahuan kepada seluruh stakeholder mengenai implikasi penggunaan rumus matematika ekonomi konvensional dalam penentuan marjin keuntungan perbankan syariah. 


\section{Maqashid Syariah: Jalan Menuju Allah}

Kehidupan yang mulia dan sejahtera di dunia dan akhirat, dapat terwujud apabila terpenuhi kebutuhan-kebutuhan hidup manusia secara seimbang. Tercukupinya kebutuhan masyarakat akan memberikan dampak yang disebut dengan maslahah. Dengan demikian, mashlahah adalah segala bentuk keadaan, baik material maupun non-material, yang mampu meningkatkan kedudukan manusia sebagai makhluk yang paling mulia. Hal ini tercapai apabila setiap aktivitas terutama ekonomi senantiasa didasarkan pada hukum Islam (Bahsoan 2011). Pada dasarnya ada tiga sasaran hukum Islam yang perlu dipahami (Daud 1996 dalam Bahsoan 2011): Pertama, penyucian jiwa, agar setiap Muslim bisa menjadi sumber kebaikan bagi masyarakat lingkungannya. Hal ini ditempuh melalui ragam ibadah yang disyariatkan dan semuanya dimaksudkan untuk dapat membersihkan jiwa dan kotorankotorannya yang melekat pada hati manusia. Kedua, menegakkan keadilan dalam masyarakat Islam. Adil baik menyangkut urusan diantara sesama kaum muslimin maupun dengan pihak non muslim. Ketiga, merupakan tujuan puncak (Maqashid Syari$a h)$ yang hendak dicapai dan harus terdapat dalam hukum Islam yaitu mashlahat atau kemaslahatan (Bahsoan 2011).

Sedangkan Luthfi (2009:169) menjelaskan bahwa setidaknya ada tiga fondasi yang dijadikan landasan dalam upaya membangun umat dan menata sebuah masyarakat, yaitu prinsip keadilan, prinsip ihsan, dan prinsip takaful. Ketiga fondasi tersebut merupakan landasan aplikatif untuk membendung dan mengantisipasi gerak al-Fasya' yaitu segala perbuatan yang didasarkan kepada pemenuhan hawa nafsu. Al-Munkar, yaitu perbuatan buruk yang bertentangan dengan akal sehat, seperti mencuri, merampok dan sebagainya. Al-Baghyu, yaitu tindakan yang mengarah kepada permusuhan. Sehingga dari penjelasan di atas dapat disimpulkan bahwa untuk mencapai maslahah sebagai tujuan utama maqashid syariah, maka setiap manusia hendaknya memperkuat tiga fondasi diri di dalam diri mereka masing-masing.

Tiga fondasi diri sebagai dasar untuk membangun umat dan menata masyarakat untuk mencapai maslahah yang pada akhirnya bermuara pada maqashid syariah menunjukkan bahwa Islam sangat memperhatikan perlindungan untuk tiap indi- vidu, yaitu melalui perlindungannya untuk semua urusan individu yang bersifat materi dan moral (Jauhar 2010:xi). Islam menjaga kehidupan tiap individu, menjaga semua yang menjadi sandaran hidupnya (harta dan semua yang dimilikinya); yang paling dasar dan pertama adalah menjaga kehormatan, yaitu nasab, tempat tumbuh, serta silsilah keturunan kepada ayah (leluhur) dan keluarganya; adapun menjaga akal yang merupakan dasar pembebanan kewajiban dan tanggung jawab dalam Islam; juga menjaga agama dan hubungan individu tersebut dengan Tuhan.

Sedangkan bentuk konsep berfikir konsumen Muslim yang hadir dalam dunia ekonomi hingga saat ini terbagi menjadi dua. Konsep pertama adalah utility, hadir dalam ilmu konvensional. Konsep utility diartikan sebagai konsep kepuasan konsumen dalam mengkonsumsi barang atau jasa. Konsep kedua adalah maslahah diartikan sebagai konsep pemetaan perilaku konsumen berdasarkan kebutuhan dan prioritas, dia sangat berbeda dengan utility yang pemetaan majemuknya tidak terbatas.

Dua konsep ini berbeda karena dibentuk oleh masing-masing epistemologi yang berbeda pula. Utility yang memiliki karakteristik kebebasan lahir dari epistemologi Smithian yang mengatakan bahwa motivasi hidup ini adalah from freedom to natural liberty (dari kemerdekaan menuju kebebasan alamiah). Dengan demikian perilaku konsumen terintegrasi dengan corak rasionalisme, dan norma agama sengaja dikesampingkan. Sementara itu, maslahah lahir dari epistemologi Islami. Sebenarnya motivasi konsep maslahah serupa dengan Smithian untuk mencapai kebebasan alamiah. Namun dalam Islam, aktulisasi diri dan peranan manusia dalam mencapai kebebasan alamiah tidak sepenuhnya dikendalikan oleh hukum rasio manusia, melainkan dikendalikan oleh risalah agama. Secara ringkas dapat dijelaskan bahwa konsep utility membentuk persepsi kepuasan materialistis sedangkan maslahah membentuk persepsi kebutuhan manusia (Bahsoan 2011).

\section{Economic Value of Time: Menelisik Hubun- gan dengan Time Value of Money}

Penggunaan economic value of time dalam ekonomi Islam tentunya sudah sesuai dengan semangat keadilan yang melekat dalam sasaran hukum Islam. Begitu pula jika pihak pelaku ekonomi juga meng- 
gunakan perangkat matematis yang sesuai dengan nilai-nilai Islam. Namun, hal tersbut akan menjadi berbalik arah ketika perangkat matematis yang digunakan juga mengakui suku bunga yang notabene diharamkan di dalam agama Islam. Hal tersebut karena meskipun perangkat matematis tersebut dianggap terpisah dengan prinsip yang mendasarinya (time value of money), namun perangkat tersebut pada hakikatnya masih merepresentasikan prinsip yang mendasarinya, atau dengan kata lain secara substansi cara tersebut masih belum lepas dari semangat ekonomi konvensional. Hal tersebut dapat dilihat dari perhitungan present value maupun perhitungan lainnya seperti penggunaan anuitas (yang akan digunakan sebagai objek "pembedahan" perangkat matematis), yang masih tetap menyandarkan diri pada konsep time value of money.

M. Yusuf Wibisana sebagai ketua DSAS IAI mengatakan bahwa industri menginginkan regulasi yang lebih agresif untuk menopang pertumbuhan pertumbuhan yang lebih besar (Akuntan Indonesia 2014). Lebih lanjut Wibisana menjelaskan bahwa kekakuan regulasi yang ada menyebabkan pertumbuhan industri syariah dalam negeri berjalan lamban, jauh berbeda dengan perkembangan perbankan syariah di Malaysia. Apa yang dijelaskan oleh Wibisana pada dasarnya memiliki kebenaran, dimana dengan menggunakan metode anuitas pihak perbankan akan semakin likuid dan pada akhirnya ketersediaan dana pembiayaan dapat dipertahankan serta nilai Capital Adequacy Ratio (CAR) sebesar delapan persen $(8 \%)$ dapat tercapai. Namun, menurut penulis hal tersebut justru akan mereduksi tujuan dan semangat yang terkandung di dalam maqashid asy-syariah dalam mengembangkan konsep ekonomi pada khususnya dan bermuamalah pada umumnya.

Reduksi maupun distorsi tujuan dan semangat tersebut dapat kita telusuri dari perhitungan rasio kecukupan modal (CAR). Perhitungan CAR dilakukan dengan cara membandingkan modal inti dan cadangan dengan dana pihak ketiga, di mana secara matematis dapat dirumuskan sebagai berikut:

$$
\mathrm{CAR}=\frac{\frac{\text { Modal Inti dan Cadangan }}{\text { Dana Pihak Ketiga }}}{100 \%}
$$

Secara lebih rinci dapat dijabarkan sebagai berikut:

$$
\mathrm{CAR}=\frac{\text { Modal }}{A T M R(C R+M R+O R)} \times 100 \%=\text { Minimal } 8 \%
$$

Berdasarkan rumus di atas penulis berusaha untuk menganalisis semangat yang mungkin timbul atas penggunaan konsep di atas. Untuk mencapai CAR minimal $8 \%$ persen pihak perbankan dapat memainkan dua hal. Pertama, pihak perbankan bisa menaikkan modal, sedangkan cara yang kedua adalah meminimalkan resiko atas penggunaan dana pihak ketiga. Ketika bank menggunakan cara yang pertama (menaikkan modal), maka bank akan berusaha keras untuk meningkatkan laba mereka. Hal tersebut karena satu-satunya cara yang paling mungkin dan besar peluangnya adalah meningkatkan laba. Bagaimana cara meningkatkan laba? Peningkatan laba erat kaitannya dengan penggunaan metode pengakuan laba. Dalam perbankan penggunaan metode anuitas tentunya lebih menguntungkan daripada jika pihak perbankan menggunakan metode proporsional. Hal tersebut karena dengan menggunakan metode anuitas maka laba yang diakui di awal lebih besar daripada laba yang di akui di akhir. Pada akhirnya pengakuan tersebut secara langsung akan meningkatkan likuiditas mereka.

Perolehan laba (banyak di awal) selain dapat membantu pihak bank mencapai nilai CAR sebesar delapan persen sebenarnya juga akan membantu pihak bank untuk memperoleh laba lagi dengan cara memberi bantuan pembiayaan kepada nasabah baru atau pun menambah pembiayaan kepada nasabah lama dari hasil perolehan laba yang banyak diakui di awal. Sehingga dari analisis tersebut dapat kita ketahui bahwa tujuan awal dari penggunaan metode anuitas adalah untuk menjaga likuiditas perbankan serta untuk meningkatkan lagi laba mereka (pihak perbankan akan lebih agresif). Keagresifan perbankan pada dasarnya lebih bertujuan untuk selalu meningkatkan laba mereka dengan cara menambah nasabah ataupun menambah "hutang" nasabah mereka untuk mereka "hisap". Berdasarkan hal tersebut dapat kita lihat bahwa praktik perbankan syariah yang ada saat ini tidak jauh berbeda dengan praktik perbankan konvensional. Semangat yang dimiliki perbankan syariah saat ini juga tidak jauh berbeda dengan semangat yang dimiliki oleh perbankan konvensional. Sebagai bukti adalah perbankan syariah lebih menyukai akad NCC 
daripada NUC. Hal ini secara tidak langsung semakin memperkuat argumen bahwa perbankan syariah maupun ekonomi Islam yang ada saat ini sebatas simbol dan nama semata, masih belum merasuk ke dalam jiwa.

Reduksi dan distorsi perbankan syariah dan ekonomi Islam, dapat kita lihat lebih jelas ketika kita membedah induk dari metode anuitas, yaitu capital asset pricing model (CAPM) yang diintrodusir oleh William F. Sharpse (1964) atas penyempurnaan model portofolio Markowitz pada tahun 1952;1959 (Fama \& French 2003). Di dalam artikel yang di tulisnya, Sharpse berusaha menjelaskan perhitungan portofolio investasi dibawah kondisi pasar yang beresiko. Secara sederhana capital asset pricing model (CAPM) dapat dirumuskan sebagai berikut.

Dimana:

$$
\mathbf{R}_{\mathrm{s}}=\mathbf{R}_{\mathrm{f}}+\boldsymbol{\beta}_{\mathrm{s}}\left(\mathbf{R}_{\mathrm{m}}-\mathbf{R}_{\mathrm{f}}\right)
$$

$\mathbf{R}_{\mathbf{s}}$ adalah Expected return on a given risky security

$\mathbf{R}_{\mathrm{f}}$ adalah Risk-free rate

$\mathbf{R}_{\mathbf{m}}$ adalah Expected return on the stock market as a whole

$\boldsymbol{\beta}_{\mathbf{s}}$ adalah Stock's beta, yang dihitung berdasarkan waktu tertentu

Berdasarkan rumus tersebut kita dapat melihat suatu "ketidakbiasaan" dalam budaya atau nilai-nilai Islam, yaitu penggunaan Risk-Free Rate. Seperti yang kita ketahui bersama di dalam budaya bisnis Islam resiko merupakan tanggungan bersama ketika kita melakukan natural uncertainty contract (NUC) seperti akad mudharabah maupun musyarakah yang biasa digunakan ketika kita melakukan kontrak bisnis, sama halnya ketika kita menginvestasikan dana kita kedalam perusahaan. Sedangkan dalam perhitungan capital asset pricing model yang notabene merupakan induk dari perhitungan anuitas dapat dilihat bahwa faktor utama yang menentukan besarnya expected return adalah risk-free rate. Mengapa perbankan syariah tetap menggunakan anuitas, bahkan DSN MUI memperkuat penggunaan anuitas menggunakan fatwa? Ketika penulis bertanya kepada dosen penulis yang notabene juga merupakan salah satu anggota DSAS beliau mengatakan bahwa:

"Di dalam Islam tidak ada larangan untuk mengakui apakah laba harus diakui secara proporsional ataukah menurun. Sedangkan bagi kebanyakan perbankan syariah metode anuitas dapat membantu likuiditas mereka. Mengapa anuitas? Karena perhitungan anuitas merupakan perhitungan yang bias menge-nol-kan jumlah uang kita di akhir. Perbankan syariah masih memerlukan benchmark, dan benchmark yang dirasa sesuai untuk saat ini adalah anuitas."

Menurut penulis apa yang dijelaskan oleh dosen penulis tersebut ada benarnya juga. Karena di dalam Islam kita diharuskan untuk menjadi seseorang yang amanah, terutama ketika kita dipercaya orang lain untuk mengelola dana mereka. Namun, sampai saat ini di masyarakat kita masih sering dan banyak terjadi moral hazard sehingga pengelolaan resiko masih diperlukan. Akan tetapi jika pembuat kebijakan tidak berusaha "menggiring" pola pikir, jiwa, dan semangat umat ke jalan murni syariah, maka sikap menggantungkan diri perbankan syariah terhadap perbankan konvensional akan tetap dan terus terjadi, terlebih lagi jika yang kita gunakan untuk melegalkan praktik adalah budaya ('urf). Padahal, di dalam ilmu ushul figh telah dijelaskan bahwa budaya ('urf) yang ada di dalam masyarakat ada dua macam, yaitu adat yang benar dan adat yang rusak (Khallaf 2003:117). Adat yang benar adalah kebiasaan yang dilakukan manusia, tidak bertentangan dengan dalil syara', tidak menghalalkan yang haram dan tidak membatalkan kewajiban. Sedangkan adat yang rusak adalah kebiasaan yang dilakukan oleh manusia tetapi bertentangan dengan syara', menghalalkan yang haram, atau membatalkan kewajiban salah satu contohnya adalah kebiasaan memakan barang riba' dan perjudian (Khallaf 2003:117-118).

Berdasarkan hal tersebut menjadi sebuah pertanyaan untuk DSN, apakah anuitas masuk ke dalam budaya yang merusak ataukah masuk budaya yang diperboehkan? Jika anuitas masuk ke dalam budaya yang merusak kenapa masih diperbolehkan? Apakah anggota DSN mempertimbangkan segala temuan yang ada, seperti adanya penggunaan risk-free rate dan budaya konsumtif yang mungkin timbul atas penggunaan capital adequacy ratio. Hal sekecil apapun haruslah dijadikan pertimbangan oleh pembuat kebijakan apalagi dalam membuat kebijakan tersebut juga ada dari kalangan ulama yang notabene memiliki tanggungan 
yang besar atas keawaman umat. Hal penting bagi ulama agama yang bermanfaat untuk orang Islam adalah, jika orang awam mengadu dan bertanya melalui lisan atau kondisi mereka, hendaknya mereka memberikan petunjuk kepada hal-hal yang dapat menjadikan keselamatan dan kebahagiaan bagi mereka di dunia dan akhirat. Menjelaskan mereka tentang sifat wara' dalam menjalani hidup. Mengajarkan kehati-hatian dalam menjalani agama. Memperingatkan mereka dari memakan harta orang dengan cara bathil. Serta memperingatkan mereka dari mendatangkan hal-hal yang diharamkan Allah, serta agar menjauhi hal-hal yang subhat dan sesuatu yang belum jelas kedudukan hukumnya (Abdullah 2011:66).

Sedangkan para praktisi dan profesional seharusnya juga menjelaskan secara detail dan rinci asal mula penggunaan suatu metode dan tidak menutup-nutupinya agar pernyataan Mannan (1992) tentang usaha para cerdik-cendekia untuk mencari dalil dan berusaha menggiring dalil yang tidak diperbolehkan menjadi dalil yang diperbolehkan tidak terjadi. Dengan begitu, pembangunan ekonomi Islam maupun perbankan syariah akan tetap dijalur yang diridhai Allah SWT sebagai usaha manusia untuk mewujudkan maqashid asy-syariah. Penggunaan anuitas seharusnya juga dikaji ulang, didalam Islam memang tidak ada aturan mengenai pengakuan laba, namun Islam mengatur mana yang baik dan tidak, mana yang halal dan haram, mana yang sesuai dengan maqashid ays-syariah dan tidak. Jika memang perbankan menginginkan pengakuan laba yang menurun pihak perbankan bisa menggunakan perhitungan sederhana yang tidak membebani kepentingan umat Muslim.

\section{SIMPULAN}

Berdasarkan penjelasan di atas dapat disimpulkan bahwa penggunaan anuitas (sebagai representasi penggunaan perhitungan matematis dalam ekonomi Islam) pada hakikatnya masih mengandung unsur semangat kapitalisme dan ketidakadilan yang notabene sudah keluar dari aturan syariah. Hal tersebut dapat kita ketahui ketika kita menelusuri asal mula kelahiran anuitas serta hubungan penggunaan anuitas dengan semangat yang terkandung dalam perhiungan capital adequacy ratio dan juga aktiva tertimbang menurut resiko. Di dalam anuitas juga masih melekat semangat pelanggengan riba', di mana anuitas masih menggunakan nilai waktu dari uang (time value of money). Sehingga dalam menggunakan perangkat matematika alangkah baiknya jika para pakar melakukan kajian kritis serta mendalam atas perangkat matematika yang akan mereka pakai agar kesesuaian antara semangat ekonomi Islam dengan praktik ekonomi Islam dapat tercapai.

\section{DAFTAR RUJUKAN}

Abdullah, Allamah Sayyid. 2011. Peringatan bagi 8 Kelompok Manusia. Penerbit Hikmah. Jakarta.

Akuntan Indonesia. 2014. Polemik Anuitas di Bank Syariah. Ikatan Akuntan Indonesia (IAI).

Ash Shadr, Muhammad Baqir. 2008. Buku Induk Ekonomi Islam Iqtishaduna. Penerbit Zahra. Jakarta.

Bahsoan, Agil. 2011. "Mashlahah Sebagai Maqashid Al Syariah (Tinjauan dalam Perspektif Ekonomi Islam)." INOVASI. Vol. 8, No. 1.

Byarwati, Anis dan Sawarjuwono, Tjiptohadi. 2013. "Ekonomi Islam atau Iqtishad?." Jurnal Ekonomi, Manajemen dan Akuntansi Islam (IMANENSI), Vol. 1 No. 1, hlm, 14-24.

Departemen Perbankan Syariah Bank Indonesia. 2012. Laporan Perkembangan Perbankan Syariah 2012.

Dewan Syariah Nasional Majelis Ulama Indonesia. 2012. Fatwa DSN MUI Nomor 84/DSN-MUI/XII/ 2012.

Fama, Eugene F \& French, Kenneth R. 2003. The CAPM: Theory and Evidence. Amos Tuck School of Business at Dartmouth College WP No. 03-26 \& Center for Research in Security Prices (CRSP) University of Chicago WP No. 550.

Jauhar, Ahmad al Mursi Husain. 2010. Maqashid Syariah. Jakarta: Penerbit Amzah.

Karim, Adiwarman A. 2011. Bank Islam: Analisis Fiqih dan Keuangan. Jakarta: Penerbit Rajawali Pers.

Khallaf, Abdul Wahhab. 2003. Ilmu Ushul Fikih. Alih bahasa A. Ma'ruf Asrori. Pustaka Amani. Jakarta.

Luthfi, Atabik. 2009. Tafsir Tazkiyah. Penerbit Gema Insani. Jakarta.

Mannan, M.A. 1992. Ekonomi Islam: Teori dan Praktek. Alih bahsa Potan Arif Harahap. Penerbit Intermasa. Jakarta. 